\title{
5. 高血圧研究の進歩
}

国立循環器病センター高血圧・腎臟科岩嶋義雄, 河野雄平

\section{はじめに}

高血圧の分野においては, 2013年にも基礎研 究, 臨床研究ともに多くの成果が発表された. 高 血圧研究の領域は幅広く, その進歩のすべてを網 羅することはできないが, 本項では第36回日本 高血圧学会総会の概要を報告することで責を果た したい.

第36回日本高血圧学会総会は, 2013年10月24 〜26日の 3 日間, 「高血圧研究と診療の進歩一最 先端のその先へ」をテーマとして, 大阪国際会議 場にて開催された。国立循環器病研究センター高 血圧・腎臟科部長の河野雄平が会長を務めた。 般演題には約 500 題の応募があり, 口演 185 題, ポスター 290 題の計 475 題が採択された. 招待講 演, シンポジウム, パネルディスカッションなど の指定演題は 123 題で, 共催セミナーや市民公開 講座などを加えた総演題数は662題となった。台 風が接近して断続的な雨の中ではあったが, 全国 から約 2,500 人が参加し, 高血圧の臨床と研究に 関する最近の知見の発表と活発な討議が行われ た. 改めて多くの関係者の方々に感謝申し上げる.

特別企画

1. 高血圧治療ガイドライン JSH2014概要

日本高血圧学会による高血圧治療ガイドライン

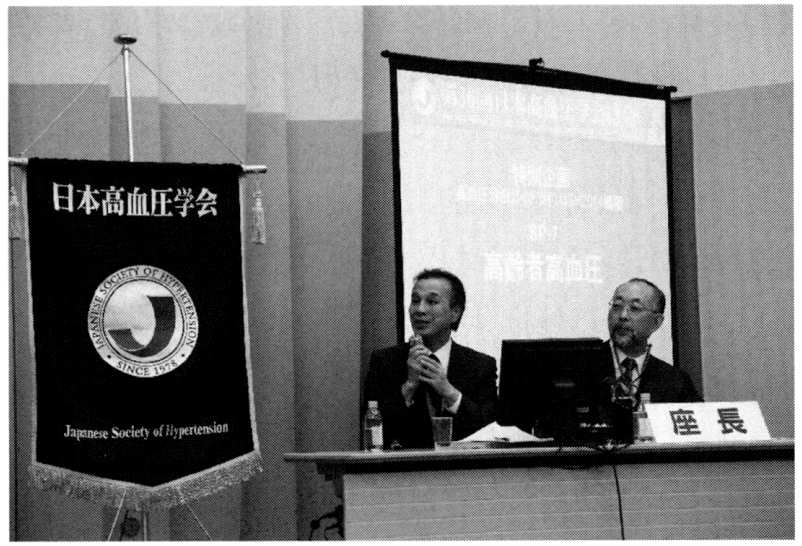

図1第36回日本高血圧学会特別企画「高血圧治療ガイ ドライン JSH2014概要」座長の島本, 島田先生

改訂版（JSH2014）は，作成の最終段階にあり， その概要が紹介された。 ガイドライン作成委員会 委員長の島本和明札幌医科大学学長と同副委員長 の島田和幸新小山市民病院院長が座長を務め, 主 な項目が担当委員により発表された（図 1)。新 しいガイドラインは, 序章に利益相反 (COI) を 明記し, 製薬企業名を公表するなどして透明性を 担保している，本稿では原案の一部を紹介する.

・血圧の評価方法

家庭での評価測定の重要性を強調して,「診察 室血圧と家庭血圧の間に診断の差がある場合に は，家庭血圧による診断を優先する」としてい る. 家庭血圧での測定回数については, 「原則 2 回測定し, その平均值」と明記している. 
図 2 特別企画「減塩サミット in Osaka 2013」のシンポ ジウム「食塩制限の課題と 方策」の演者と討論者

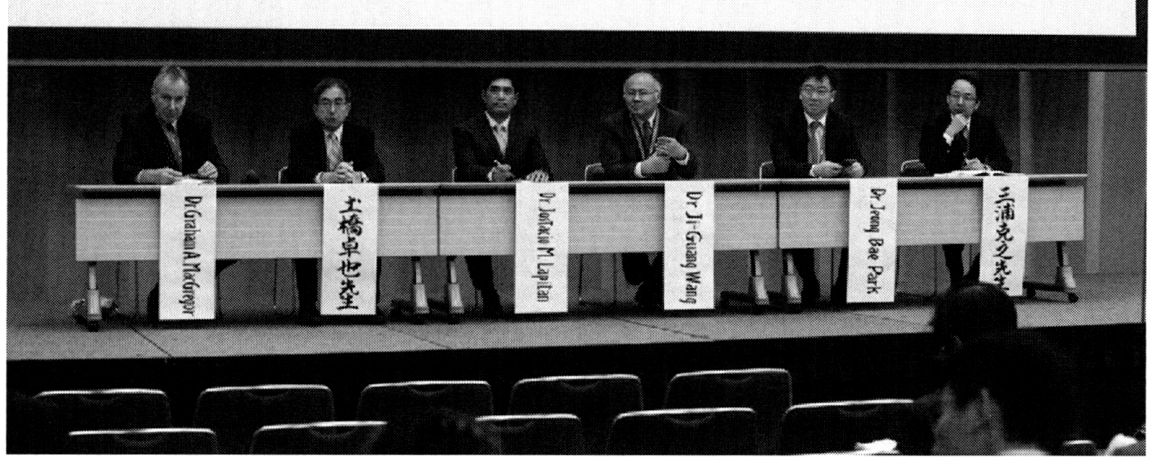

な減塩活動を推進している。2012年には本学会 が共催しての減塩サミット in 呉2012が開催され, 大きな成功を収めた。今回は第36回日本高血圧 学会総会の一部として，以下のプログラムからな る減塩サミット in Osaka 2013が企画された.

・シンポジウム：食塩制限の課題と方策（座長： 上島弘嗣，松浦秀夫）

日本 (三浦, 土橋), 韓国 (Park) 中国 (Wang), WHO (Lapitan) のシンポジストに, 英国の MacGregor 教授も討論に加わり，発表と討論 が行われた（図2）。

・メディカル・コメディカル合同シンポジウム： 減塩活動と減塩指導（座長：土橋卓也, 三浦克 之)

消費者庁からの演者を含む 4 人のシンポジス トにより, 減塩活動と減塩指導, 食品の栄養表 示について発表, 討論がなされた.

・ランチョンセミナー：(座長：河野雄平, 演者 : Graham MacGregor)

Salt: Time for Action in Japan と題する講演 で，減塩の重要性と日本での行動を啓発され た.

・一般演題（口演，ポスター）

・減塩食品，減塩活動展示

20 以上の企業や団体による減塩食品の展示と 
減塩活動の紹介が行われ, 学会員に加えて一般 市民も参加された.

-市民公開講座：よい生活習慣と健康長寿（座 長：内藤博昭, 河野雄平)

土橋卓也, 高木洋子, 家森幸男, 西川ヘレン の 4 氏による講演が行われ, 多数の市民が参 加された。

\section{特別講演 ·招待講演 ·会長講演}

\section{1. 特別講演}

国立循環器病研究センター研究所長の寒川賢治 先生に，「新規ぺプチドの探索・発見は何をもた らしたか？」のタイトルでご講演いただいた（図 3）。これまでに生理活性ペプチド（ナトリウム 利尿ペプチド，アドレノメデュリン，グレリン， なざ）を多数発見されてきた業績とともに，最近 の知見を紹介された.

\section{2. 招待講演}

招待講演として, 6 人の先生を招聘しご講演い ただいた.

- Prof. Ernesto L. Schiffrin (McGrill University, カナダ)

国際高血圧学会（ISH）の会長であるSchiffrin 教授は，2013年に改訂された欧州高血圧学会 (ESH) /欧州 (ESC) 高血圧治療ガイドライン1) について講演された。同ガイドラインは，ほと んどの患者の降圧目標を $140 / 90 \mathrm{mmHg}$ 未満と している。.また， $\beta$ 遮断薬は主要降圧薬として 残つている.

- Prof. Anna F Dominiczak (University of Glasgow，英国)

ESHの会長で，Hypertension 誌の編集長で もある Dominiczak 教授は, 高血圧の遺伝学 について講演された。ゲノムワイド関連研究 (GWAS) データのメ夕解析の結果や2), 血圧 の遺伝学・生物学に関する新しい視点を概説さ れた。

- Prof. Jan A Staessen (University of Leuven,

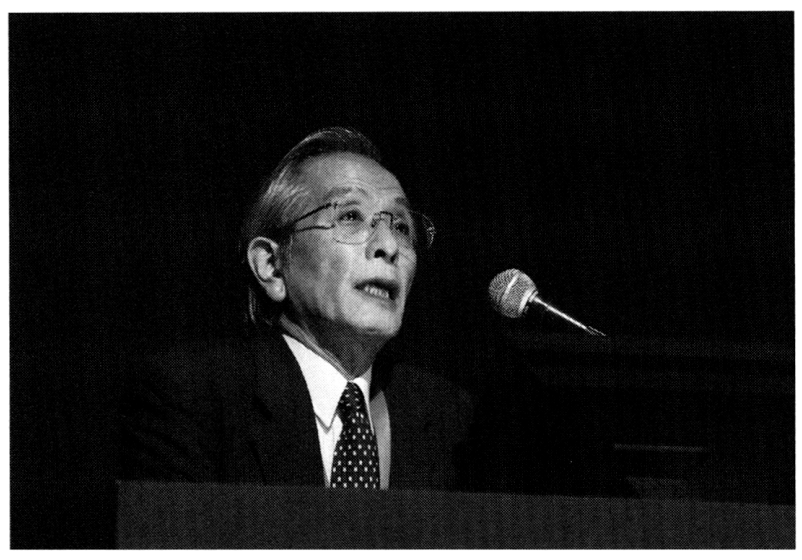

図 3 特別講演の寒川賢治先生

ベルギー)

これまで数多くの大規模臨床試験に関わられて いる. 今回は，24時間血圧測定を用いた国際 的共同研究 $(\mathrm{IDACO})^{3)}$ などの結果を含めて, 診察室外での血圧測定の重要性について解説さ れた。

- Prof. Carlos M Ferrario (Wake Forest University, 米国)

レニン・アンジオテンシン系の研究では, 血管 拡張作用を有するアンジオテンシン-(1-7) の 役割の解明に大きな貢献をされている。 今回 は，アンジオテンシンー(1-12) や，ACE 活性 と心筋のリモデリングの関わりについて解説さ れた4).

- Prof. Murray D. Esler (Baker IDI Heart and Diabetes Institute，オーストラリア) 交感神経系研究で高名で，治療抵抗性高血圧に 対するアブレーションカテーテルによる腎除神 経の臨床試験の結果5,6)を紹介された。また, 様々なデバイスが開発中であることも紹介され た.

- Prof. Suzanne Oparil (University of Alabama at Birmingham, 米国)

米国の高血圧診療ガイドライン JNC8 の策定委 員会の共同委員長であり, JNC8 についての解 説を期待したが，残念ながら学会開催までに発 表されなかった．高血圧治療の第一選択薬，多 剂併用療法の有用性，難治性高血圧への対処な 
ぞについて講演された.

\section{3. 会長講演}

国立循環器病研究センターの河野は, 「高血圧 研究のオデュッセイア」の題で会長講演を行っ た. 世界の高血圧研究の歴史と日本人研究者の貢 献, 日本高血圧学会の歴史, 自身の高血圧研究に ついて総括し, 今後の高血圧研究のさらなる発展 に期待を寄せた.

\section{ハポジウム・パネルディスカッション}

シンポジウムは，上記以外に「レニン・アンジ オテンシン・アルドステロン系研究の最前線」, 「日本の高血圧疫学研究: 最新の知見」,「日本に おける臨床試験のあるべき姿を考える」,「血管作 動性物質研究の最先端」, 「心臟病と高血圧：診療 と研究の最前線」,「腎臓病と高血圧: 診療と研究 の最前線」,「メディカル・コメディカル合同シン ポジウム」が設けられた. 他学会との合同シンポ ジウムは, 日本脳卒中学会, 日本妊娠高血圧学 会, 日本超音波学会, 日本プライマリケア学会と の 4 つが行われた。 また, パネルディスカッショ ンとして,「血管と高血圧」,「生活習慣病とメ夕 ボリックリスクファクター」,「血圧変動と家庭血 圧，24時間血圧」，「高血圧遺伝子研究」，「神経 系と高血圧研究」が取り上げられた。本稿では, 「日本における臨床試験のあるべき姿を考える」 について報告する.

・シンポジウム「日本における臨床試験のあるべ き姿を考える」

菊池健次郎先生（北海道循環器病院）, 瀧下修 一先生（沖縄リハビリテーション福祉学院）が 座長を務められ，有馬久富（シドニー大学）, 植田真一郎 (琉球大学), 漆原尚巳 (慶應義塾 大学), 稲垣治 (日本製薬工業協会), 宮田靖志 (北海道大学), の先生方が発表, 討論された (図 4).

臨床研究の不正の防止策として, (1)論文を科学 的に公正に吟味する能力の向上, (2)生物統計・臨

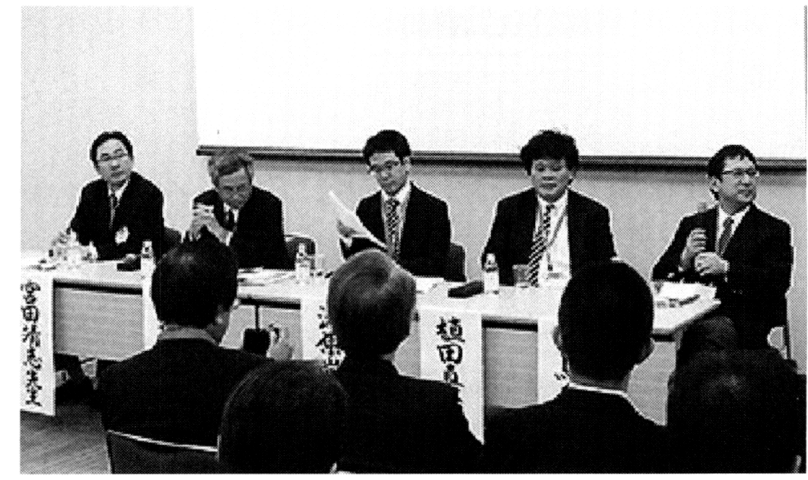

図 4 シンポジウム「日本における臨床試験のあるべき 姿を考える」の演者の先生方

床疫学等の専門家の育成, (3)研究者の倫理的資質 の向上システムの構築，(4)臨床研究者の認定制度 の導入，などが提言された．また，プロトコル作 成から統計解析・論文作成まで，スポンサーとは 独立した公的またはそれに準ずる組織が，一貫し て業務に携わるシステムの構築が防止策のひとつ となることや, ICH-GCP が適用されない臨床試 験や研究における質，信頼性をどのように担保す るか，医師と製薬企業との適切なかかわり方，な どについて議論された。座長からは，COIの開 示，企業からの働きかけや研究に対する公正かつ 中立的な姿勢を保つこと，科学的根拠に欠ける情 報提供は企業の宣伝への加担になりうることの自 覚の必要性, などがコメントされた.

\section{その他}

・フォーカスセッション：「高血圧診療における 血管機能検査 (FMDJ 研究から)」

・ディベート：「高血圧治療の第一選択薬：カル シウム拮抗薬 vs. アンギオテンシン受容体拮抗 薬」,「高血圧診療におけるバイオマーカーの 有用性：有用vs. 無用」

・ハンズオンセミナー：頸動脈エコー，心臓エ コー, 腎動脈エコー, $\mathrm{PWV} / \mathrm{AI}$ 中心血圧

・ランチョンセミナー：「国循の美味しい！ か るしおレシピ」に基づく減塩弁当を提供した.

・医療倫理・医療安全講演会 
・市民公開講座：3 日間に 3 つの市民公開講座を 開催した。

\section{おわりに}

第36回日本高血圧学会総会の概要を紹介した. 高血圧の研究と診療は進歩が目覚ましく，完成の 域に近づいたようにもみえるが，まだわかってい ないことも多い。本学会は, 最先端の研究成果を 発表していただき，さらにその先に進めればとの 思いで企画し，招待講演やシンポジウムととも に，一般演題も重視した。また2012年は，降圧 薬を用いた臨床研究の不正が問題となつた。 日本 高血圧学会は，倫理委員会や臨床試験に関わる在 り方委員会を設置しここの問題に取り組んでい る. 高い倫理性と信頼性を備えた研究により, 高 血圧の研究と診療がさらに進むことを願ってい る.

著者の COI (conflicts of interest) 開示 : 本論文発表 内容に関連して特に申告なし

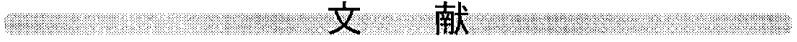

1) Mancia G, Fagard R, Narkiewicz K et al: 2013 ESH/ ESC Guidelines for the management of arterial hypertension: the Task Force for the management of arterial hypertension of the European Society of Hypertension (ESH) and of the European Society of Cardiology (ESC). J Hypertens 2013; 31: 1281-1357

2) Ehret GB, Munroe PB, Rice KM et al: Genetic variants in novel pathways influence blood pressure and cardiovascular disease risk. Nature 2011; 478 (7367) : 103-109

3) Kikuya $M$, Hansen TW, Thijs L et al: Diagnostic thresholds for ambulatory blood pressure monitoring based on 10-year cardiovascular risk. Circulation 2007; 115: $2145-2152$

4) Dell'Italia LJ, Ferrario CM: The never-ending story of angiotensin peptides: beyond angiotensin I and II. Circ Res 2013; 112: 1086-1087

5) Krum H, Schlaich M, Whitbourn R et al: Catheter-based renal sympathetic denervation for resistant hypertension: a multicentre safety and proof-of-principle cohort study. Lancet 2009; 373 (9671) : 1275-1281

6) Esler MD, Krum H, Sobotka PA et al: Renal sympathetic denervation in patients with treatment-resistant hypertension (The Symplicity HTN-2 Trial): a randomised controlled trial. Lancet 2010; 376 (9756) : 19031909 